\title{
História da Educação no Brasil: a constituição histórica do campo (1880-1970)
}

\author{
Diana Gonçalves Vidal ${ }^{2}$ \\ Universidade de São Paulo \\ Luciano Mendes de Faria Filho ${ }^{3}$ \\ Universidade Federal de Minas Gerais
}

Resumo

O artigo aborda a constituição do campo da história da educação no Brasil de dois prismas. No primeiro, elabora um histórico da disciplina a partir de três pertencimentos: à tradição historiográfica do Instituto Histórico e Geográfico do Brasil (IHGB); às escolas de formação para o magistério e à produção acadêmica entre os anos 1940 e 1970. No segundo, enfoca os trabalhos realizados nos últimos 20 anos, apontando temas e períodos de interesse e abordagens teóricas mais recorrentes.

Palavras-chave: Historiografia; História da Educação; Educação.

\section{ABSTRACT}

This article tackles on the structuring of the field of history of education in Brazil through two angles. The first one elaborates on the history of the discipline from three views: the historiographic tradition of the Historical and Geographical Institute of Brazil ( IHGB); the development of teacher's colleges and the academic production from 1940 to 1970. The second one, focus on works done during the last 20 years, pointing out to topics, periods of interest and the most recurrent theoretical approaches.

Keywords: Historiography; History of Education; Education.

A partir do fim dos anos 1960 e início dos 70, com o surgimento dos Programas de Pós-Graduação em Educação no país (o da PUC-Rio, em 1965, e da PUC-SP, em 1969, foram os primeiros a se constituir), e dos anos 1980, com a criação do Grupo de Trabalho "História da Educação" da Associação Nacional de Pós-Graduação e Pesquisa em Educação (ANPEd), em 1984, e do Grupo de Estudos e Pesquisas "História, Sociedade e Educação no Brasil" (HISTEDBR), em 1986, cresceu substantivamente a produção de trabalhos em História da Educação no Brasil. Ao mesmo tempo foi-se constituindo uma certa identidade, ainda que multifaceta e plural do historiador da educação. No entanto, já desde a segunda metade do século XIX, tratados sobre história 
da educação brasileira foram elaborados por médicos, advogados, engenheiros, religiosos, educadores e historiadores e circularam no País e no exterior.

A vitalidade da área, percebida nestes últimos trinta anos, tem sido objeto de reflexão de pesquisas acadêmicas ${ }^{4}$ e de vários balanços efetuados ao final de Congressos de História da Educação, como o I Congresso Brasileiro de História da Educação ${ }^{5}$ e os I a IV Luso-brasileiro de História da Educação $0^{6}$; ou por encomendas de Grupos de Trabalho, como o GT História da Educação da ANPEd ${ }^{7}$ e HISTEDBR ${ }^{8}$. Os estudos têm buscado delinear um panorama da atual historiografia em educação, destacando temáticas e períodos privilegiados pela pesquisa, bem como aportes teóricos mais recorrentes nessa escrita disciplinar.

A produção inicial do campo também vem sendo investigada, ainda que de maneira esporádica, revelando-se um objeto recente de interesse ${ }^{9}$. Pretendendo contribuir para a compreensão histórica da configuração do campo da História da Educação no Brasil, sistematizando a bibliografia disponível sobre a temática e propondo um novo ordenamento para a análise, este artigo almeja perceber matizes dessa escrita concebida como operação historiográfica ${ }^{10}$.

Debruçar-se sobre a história (ou histórias) da disciplina, no desenho de vertentes que a compõem, não é tarefa simples. Implica efetuar escolhas, constituir hierarquias, elaborar análises que, ao mesmo tempo que conferem uma inteligibilidade à narrativa, instituem um passado (portanto, erigem uma memória) para o campo. Elucidar as escolhas feitas e as hierarquias construídas não impede os efeitos dessa inversão escriturária ${ }^{11}$, mas oferece ao leitor outras chaves de leitura do texto histórico. Nesse sentido, é necessário esclarecer inicialmente que as obras utilizadas para este estudo foram selecionadas a partir de dois critérios: a) atribuir-se o objetivo de versar sobre a história da educação, muitas vezes explícito no título, como, por exemplo, a Pequena história da educação, das madres Peeters e Cooman ${ }^{12}$; b) ser reconhecida no campo por obra de referência sobre a história educacional, mesmo que o autor não a tenha constituído como tal, como acontece com A cultura brasileira, de Fernando de Azevedo ${ }^{13}$.

Em segundo lugar, é forçoso dizer que as três vertentes, a seguir esboçadas, configuraram-se levando-se em conta os alertas de De Certeau ${ }^{14}$ sobre a operação historiográfica, considerada como uma relação entre um lugar, percebido de maneira abrangente como recrutamento, meio ou ofício, procedimentos de análise e construção de um texto. O fato de as termos distinguido, 
entretanto, não significa que exaurimos as várias combinações que as obras suscitavam. Outras leituras poderiam levar a entrecruzamentos diversos e novas classificações. Aliás, algumas mediações aparecem no interior mesmo de cada vertente, apontando para outras possibilidades de enquadramento dos trabalhos no campo.

Por fim, cumpre explicitar que as operações aqui propostas se fizeram tanto mais necessárias na medida em que o entendimento da história da educação como um campo autônomo, apartado da filosofia da educação, é fenômeno recente e não de todo consolidado no seio da Pedagogia. Essa questão, contudo, será esclarecida com o decorrer da narrativa.

\section{PRIMEIRA VERTENTE: A HISTÓRIA DA EDUCAÇÃO e o Instituto Histórico e Geográfico Brasileiro}

"Le Brésil n'est pas tout à fait en retard sur la civilisation européenne”. Assim Frederico José de Santa-Anna Nery concluía o artigo "L’instruction publique au Brésil”, publicado na Revue Pédagogique em $1884^{15}$. Em vinte páginas escritas em francês, o autor, utilizando-se de malabarismos estatísticos, empenhava-se em demonstrar a pujança da instrução pública no Brasil que, em 1877, ostentava uma freqüência escolar 12\% superior à francesa (de acordo com os cálculos do autor). Esse não era o primeiro texto sobre educação brasileira elaborado, nem a fórmula de apresentar estatísticas como comprobatórias do progresso intelectual, inédita. Antes dessa publicação, os livros $O$ Império do Brasil, editados em 1867, 1873 e 1876, sob os auspícios governamentais, traziam no capítulo "Cultura intelectual", dados quantificadores da presença de alunos nos vários ramos e instituições educacionais e culturais existentes no país ${ }^{16}$. Escritas para figurar nas Exposições Universais, as obras eram peças de propaganda do Estado Imperial.

As contribuições de Santa-Anna Nery sobre a educação brasileira não se restringiram, entretanto, ao artigo citado. Esse paraense ${ }^{17}$, antigo aluno do Seminário de Manaus, que após receber as ordens menores no Seminário de Saint-Sulpice, em Paris, abandonou a carreira eclesiática bacharelando-se em Letras, em 1867, ficou conhecido pelos livros, redigidos em francês, sobre a Amazônia (Les pays des Amazones. L'El-Dorado. Les terres à cahoutchouc. Orné de 101 illustrations et de 2 cartes explicatives avec un portrait de l'autheur, gravé à l'eau-forte par Robet Kemp. Paris, Bibliothèque des Deux-Mondes, $1885^{18}$ ) e sobre o folclore brasileiro (Folk-lore brésilien: poésie populaire.contes et légendes.—fables et mythes.—poésie, musique, danses et croyances des Indiens; accompagné de douze morceaux de musique. Préface du prince Roland Bonaparte. Paris : Perrin, $\left.1889^{19}\right)$. Organizou, também, a obra Le Bré- 
sil en 1889 (avec une carte de l'empire en chromolithographie, des tableaux statistiques, des graphiques et cartes. Paris: Charles Delagrave, 1889), composta de vários capítulos escritos por colaboradores eminentes, dentre eles um sobre instrução pública que assinava, ao lado do barão de Sabóia, de Louis Cruls e do barão de Teffée ${ }^{20}$. Editado sob os cuidados do Comitê Franco-Brasileiro para a Exposição Universal de Paris, ocorrida naquele mesmo ano, a obra era apresentada por M. Daubrée. Nela, mais uma vez com recurso a dados estatísticos, relativos a 1869, 1876, 1882 e 1889, Nery procurava atestar o progresso intelectual brasileiro na contabilidade da difusão de escolas primárias públicas e na freqüência de alunos, que chegava a avaliar em $300.000^{21}$.

O primeiro livro voltado exclusivamente a narrar a história da educação brasileira, L'Instruction publique au Brésil: histoire et legislation (1500-1889), de José Ricardo Pires de Almeida, composto como elogio ao Império e publicado já no fim do regime (em 1889), movia-se, da mesma forma, no âmbito das estatísticas e continha objetivo semelhante: afirmar a liderança brasileira em termos educacionais. Mas agora o alvo eram os países sulamericanos, em especial a Argentina. Dizia-se o autor constrangido ao "dever e quase missão de restabelecer a verdade": "O Brasil é, certamente, dentre todos os paises da América do Sul, aquele que maiores provas deu de amor ao progresso e à perseverança na trilha da civilização" ${ }^{22}$. A contenda com a Argentina espraiava-se na demonstração da superioridade do regime monárquico sobre o republicano ${ }^{23}$.

Dedicado ao conde D’Eu, futuro governante brasileiro na hipótese remota de uma manutenção do Império, o livro, redigido em francês, "língua universalmente conhecida", de acordo com seu autor, discorria particulamente sobre a educação no pós-Independência. A época colonial era abordada apenas na Introdução ao volume, indiciando sua pequena relevância, apesar de nela se inscrever o esforço precursor dos jesuítas, sumariamente descrito nas cinco páginas iniciais; as iniciativas pombalinas, narradas nas dez páginas seguintes; e o evento fundador da educação no Brasil, a chegada de D. João VI, começo de uma verdadeira "constituição da nacionalidade brasileira, nacionalidade proclamada em dezembro de $1815^{\prime 24}$.

A instrução pública primária e secundária depois da Independência era tratada em duas épocas: até o Ato Adicional, portanto de 1822 a 1834, em parcas 10 páginas; e do Ato "aos dias de hoje", ou seja, de 1834 a 1889, em 245 páginas. A segunda época comportava, ainda, uma divisão interna entre dois períodos: de 1834 a 1856 (34 páginas) e de 1857 a 1889 (211 páginas), tomados para maior comodidade do leitor ${ }^{25}$ e entrecortando a gestão do ministro do Império, conselheiro Luiz Pedreira do Couto Ferraz. A análise procedia de um levantamento das leis criadas pelo Estado e recorria ao tom encomiástico no elogio às ações da família imperial no campo educativo.

Médico, formado no Rio de Janeiro, e estudante de Direito por três anos 
em São Paulo, Pires de Almeida havia sido arquivista da Câmara Municipal e adjunto da Inspetoria Geral de Higiene na Corte, onde trabalhara nos serviços de arquivo e biblioteca ${ }^{26}$, o que, por certo, muito lhe facilitara o levantamento de informações para a elaboração do livro. Sua produção escrita variava bastante, versando sobre imigração italiana, economia doméstica, carnaval, montepio civil, saneamento de Petrópolis, dentre muitos outros temas $^{27}$. Publicou, em 1906, Higiene Moral — homossexualismo (A libertinagem no Rio de Janeiro: Estudo sobre as perversões do instinto genital. Rio de Janeiro: Laemmert \& Co.), onde afirmava que a degradação do homem davase pela alimentação excitante ou picante, pelo apetite venéreo, pela imaginação ardente e, também, pelos bailes populares, os cafés-dançantes e a organização das sociedades carnavalescas ${ }^{28}$. A obra servia, para Nunes, como contraponto a L'instruction publique au Brésil, na medida em que permitia a Pires de Almeida, pelo avesso, retomar o projeto de intelectualidade a que estava vinculado e que explicitara nos comentários finais do livro sobre educação: "o historiador tem, em qualquer país, o dever de esclarecer o papel de seu país no mundo e investigar detalhadamente as questões obscuras que interessem às origens nacionais" ${ }^{29}$.

Membro honorário do Instituto Histórico e Geográfico Brasileiro (IHGB), Pires de Almeida partilhava de seus objetivos de coligir, metodizar, publicar ou arquivar os documentos necessários para a história e a geografia do Império ${ }^{30}$, respeitando uma postura positivista de escrita da história. Tal parece ser o móvel da reprodução, em anexo, de documentos citados sobre o período colonial e da inclusão de vários excertos de relatórios e de leis no corpo de L'Instruction publique au Brésil. Partilhava também do projeto do IHGB de "desvendamento do processo de gênese da Nação" brasileira, percebida como "continuadora de uma certa tarefa civilizadora iniciada pela colonização portuguesa” ${ }^{\prime 1}$. Nesse movimento de construção identitária da Nação pelo IHGB, distinguir-se do outro era necessário, seja internamente apartando-se dos negros e índios, porque não portadores da noção de civilização; seja externamente das repúblicas latinoamericanas, porque ameaças à forma de governo monárquico e representação da barbárie ${ }^{32}$. A chegada de D. João VI como marco fundador da educação no Brasil, o elogio ao Império, as estatísticas circunscritas à população livre, bem como a disputa com a Argentina, na escrita de Pires de Almeida engendravam o mesmo padrão narrativo a que se entregavam os letrados em torno do IHGB.

Se não podemos afirmar a filiação de Santa-Anna Nery ao IHGB (ou ao Institut Historique de Paris, referência ao trabalho historiográfico e à visão de história do IHGB, nos primeiros anos de sua criação, de acordo com o já citado Manoel Guimarães), como o fizemos para Pires de Almeida, podemos destacar a proximidade do discurso de ambos no tocante à descrição e à in- 
terpretação dos fatos da instrução pública. A ligação clara entre Pires de Almeida e o Instituto Histórico, matriz da tradição historiográfica brasileira, no entanto, estabelece de maneira inesperada um vínculo entre disciplinas que aparentemente dispunham de trajetórias apartadas.

Traduzido para o português somente em 1989, cem anos após sua edição original, L'Instruction publique au Brésil não ficou no limbo da historiografia educacional brasileira, desconhecido pelos autores nacionais até tempos recentes. Ao contrário, referência de boa parte da bibliografia posterior sobre história da educação, Pires de Almeida viu-se citado, dentre outros, por Júlio Afrânio Peixoto, em Noções de história da educação, de 1933³3; Primitivo Moacyr, A instrução e o Império: subsídios para a história da educação no Brasil, 1823-1853, de 1936 $6^{34}$; Fernando de Azevedo, A cultura brasileira, de 194335; e Theobaldo Miranda dos Santos, Noções de história da educação, de $1945^{36}$. Julgá-lo como um texto "não fundador" de uma narrativa histórica em educação, como o fez Nunes ${ }^{37}$, por não ter sido destinado ao ensino nas Escolas Normais, parece-nos dissolver sua importância na construção de uma tradição historiográfica em educação. Mais sugestivo talvez seja investigar a relação entre o IHGB e a escrita da história da educação, indiciada por Pires de Almeida, explorando vertentes desse fazer historiográfico.

Moysés Kuhlmann Jr. ${ }^{38}$ iniciou tal percurso. Destacou as contribuições de Benjamin Franklin Ramiz Galvão na sistematização de fontes para uma história da instrução pelo arrolamento de livros e artigos sobre a educação, relatórios, memórias, regulamentos e estatutos de escola, conferências e discursos, pareceres e projetos de lei, efetuado na classe História Literária e das Artes do Catálogo que organizou para a Exposição de História do Brasil, de 1881. Na coordenação do Livro do Centenário, elaborado agora às portas do regime republicano, em 1900, com o intuito de "dar a conhecer as riquezas naturais do Brasil e seus progressos em todos os ramos da atividade humana"39, em que José Veríssimo Dias de Matos assinava o capítulo "A instrução e a imprensa: 1500-1900”. E, por fim, na organização do Dicionário Histórico, Geográfico e Etnográfico Brasileiro, publicado pelo IHGB por ocasião do centenário da Independência, que apresentava o capítulo 15 sob o título de "Instrução pública, notícia histórica de 1822 a 1922”, de autoria de M.P. Oliveira Santos.

Nessas publicações posteriores à instalação do regime político republicano não se alteraram significativamente as propostas de coligir e metodizar documentos (inscritas nos Estatutos do IHGB, elaborados em 1839, um anos após a criação do Instituto), nem de interpretar a gênese da civilização brasileira, ambas caras à tradição narrativa da história gestada pelo IHGB. Na esteira de tais preocupações outras obras, dedicadas especificamente à história da educação, poderiam ser arroladas, demonstrando a permeabilidade da pro- 
dução historiográfica em educação à visão de história e do fazer historiográfico presentes no Instituto.

A publicação do primeiro volume de $A$ instrução e o Império: subsídios para a História da Educação no Brasil, 1823-1853, de Primitivo Moacyr, em $1936^{40}$, inaugurou uma vasta obra, que até 1942 foi responsável pelo levantamento e compilação de leis, estatutos e regimentos escolares, memórias, relatórios e pareceres sobre instrução pública e particular nos vários ramos de ensino (primário, secundário, profissional e superior) no Brasil. Ao todo, foram editados 15 volumes, três dedicados à Instrução e o Império (entre 1936 e $1938)^{41}$, três à Instrução e as Províncias (entre 1939 e 1940) ${ }^{42}$ e sete à Instrução e a República (entre 1941 e 1942) ${ }^{43}$, além de dois à Instrução pública no Estado de São Paulo $(1942)^{44}$ e um à Instrução primária e secundária no município da Corte $(1942)^{45}$.

O volume inicial da série era prefaciado por Afrânio Peixoto que, estabelecendo uma relação de semelhança entre o trabalho de Moacyr e Varnhagen, afirmava o livro como matéria prima de novos estudos em educação, posto que: "No Brasil não se pesquisa. Todos tiramos de nós a substância de nossos escritos. A história nessas condições é repetição, é comentário, é fantasia interpretativa" ${ }^{\prime 4}$.

Sem introdução ou conclusão, o livro se estendia por 614 páginas, ao cabo das quais uma pequena bibliografia relacionava além das Coleções de Leis do Reino de Portugal e do Império do Brasil, dos Anais da Assembléia Geral Legislativa e dos Relatórios do Ministério do Império, o livro L’instruction publique au Brésil, de Pires de Almeida, e os artigos "Cem anos de ensino primário (1826-1926)" (In: Centenário do Poder Legislativo), de Afrânio Peixoto, e "A instrução pública nos tempos coloniais" (Revista do IHGB), de Moreira de Azevedo. Foi publicado pela Cia. Editora Nacional, integrando a série V, Brasiliana, da Biblioteca Pedagógica Brasileira, projeto coordenado por Fernando de Azevedo para a editora, desde sua criação em 1931 até 1946. Os demais volumes editados até 1939, referentes ao Império e às Províncias, apresentavam características semelhantes, mesmo número aproximado de páginas, mesma ausência do autor, que se limitava a compilar documentos ${ }^{47}$, mesmo pertencimento à Brasiliana. Os dois volumes sobre a instrução paulista diferiam apenas no número de páginas reduzido para em torno de 250 e incluíam na bibliografia os livros Um retrospecto, de João Lourenço Rodrigues, e O ensino em São Paulo, de J. Feliciano de Oliveira. Já os volumes relativos à República apresentavam traços diferentes. As páginas mantinham-se em aproximadamente 200 por volume, o formato abandonara o $12 \times 18 \mathrm{~cm}$, assumindo o tamanho de $18 \times 22,5 \mathrm{~cm}$, a bibliografia ostentava outros títulos, como José Veríssimo, A educação nacional. Passava a obra a ser publicada pela Imprensa Nacional, sob a orientação do Instituto Nacional de Estudos Pedagógicos 
(INEP) do Ministério da Educação e Saúde, órgão dirigido por Manoel Bergström Lourenço Filho, de 1938 (ano de sua criação) até 1946.

A breve caracterização realizada acima suscita desdobramentos. O primeiro relaciona-se à vinculação de Primitivo Moacyr ao IHGB, seja pelo primado de coligir e metodizar documentos, seja pelo recurso às publicações do Instituto e autores a ele ligados na elaboração do texto, seja ainda pelo elogio inicial, feito por Peixoto, que situa Moacyr como herdeiro de uma tradição que remonta a um dos personagens mais célebres do Instituto, seu antigo secretário, Varnhagen. O segundo refere-se à inserção da obra na Biblioteca Pedagógica Brasileira e ao acolhimento do projeto editorial pelo INEP, demonstrando a inequívoca relação de Moacyr com a área educacional, quer pelo patrocínio recebido, quer pela aproximação com os já renomados educadores Azevedo e Lourenço Filho, que se estende a Anísio Teixeira. Este último, no Prefácio ao volume 3 de $A$ instrução no Império, afirmava:

"Aliás já lhe disse que o primeiro volume me mostrou como esse foi - e não será ainda? - o defeito capital dos educadores brasileiros. Estivemos todo o tempo com grandes planos gerais, com debates de princípios, chocando ideais educativos. E nada de lhes estudar os problemas concretos, de lhes analisar as necessidades típicas, de examinar as dificuldades e facilidades características de execução, de realização" ${ }^{48}$.

As obras repertoriadas acima, entretanto, não foram as primeiras de Moacyr. No ano de 1916, havia publicado O ensino público no Congresso Nacional: breve notícia ${ }^{49}$. No livro, podia-se identificar a mesma preocupação em compilar leis e relatórios constatada anteriormente, no entanto, em curtos parágrafos ao início e ao fim do texto, o autor anunciava suas intenções: " $a$ opinião publica é talvez injusta quando acusa o Congresso de desapreço às cousas do ensino público" ${ }^{\prime 50}$. Ao longo de 200 páginas Moacyr enumerava as iniciativas do governo republicano nos 24 anos de existência (entre 1889 e 1914), com o fito de oferecer um "modesto subsídio aos homens de boa vontade na solução (...) do problema de nosso apparelhamento economico e, mais, de integração nacional’’s1.

Advogado, Primitivo fez carreira como funcionário da Câmara dos Deputados, desde 1895, quando ingressou como redator de debates, até sua aposentaria em $1933^{52}$. Sua familiaridade com os arquivos parlamentares facilitaram-lhe, por certo, a tarefa de compilação efetuada. Tal qual Pires de Almeida, apoiando-se numa visão positiva de história, Moacyr, como aquele, apesar de sua pretendida neutralidade manifestou seus propósitos. Aqui já não o elogio ao Império, mas o reconhecimento da importância da função parlamentar na organização e constituição da instrução pública.

Os sete volumes d' A Instrução e a República, de Moacyr não foram o único investimento do INEP na divulgação de documentos úteis à história da 
educação nacional. Tendo sido constituído com a função, dentre outras, de "organizar a documentação relativa à história e à situação atual da educação no país"53 , o Instituto deu início em janeiro de 1940 à elaboração dos Subsídios para a história da educação brasileira ${ }^{54}$, série composta por onze volumes editados entre 1942 e 1951, contendo a relação dos "atos e fatos de maior importância na vida educacional do paîs" ${ }^{\prime 5}$, de caráter oficial ou iniciativa privada, em todos os Estados nos anos de 1940 a 1950. A série, constituída para subsidiar as leis orgânicas criadas no governo Vargas, manteve características idênticas em todo o período, apesar da edição das citadas leis, entre 1942 e 1946, e de, nos anos finais, a direção do Instituto ter sido entregue a Murilo Braga de Carvalho. Uma pequena introdução, assinada pelo diretor do INEP, destacava os aspectos considerados mais relevantes para a educação no ano. Seguiam-se ordenadas por mês, na seqüência dos dias, as notícias, intercalando as várias unidades federativas.

O INEP dispunha ainda de "prontuários sistemáticos, referentes à legislação do governo central, na colônia, no império e na república, e que remetem a repertório dessa legislação, desde 1808 a esta data; como dispõe também de repertórios da legislação dos Estados" ${ }^{56}$. Apesar dos esforços do Instituto na compilação e difusão de documentos sobre a educação nacional, ao longo dos anos 1950 cresceram as dificuldades para a execução de pesquisas, posto que o INEP vinha se transformando em órgão de caráter eminentemente legislador $^{57}$. Ao assumir sua direção em 1952, Anísio Teixeira, com o intuito de revigorar a investigação sobre a situação do ensino no território nacional, dedicou-se a constituir um locus privilegiado de realização de levantamentos de dados e análises, subsidiados por cientistas sociais, e de sua divulgação. Em 1955 era criado o Centro Brasileiro de Pesquisas Educacionais (CBPE), ligado ao INEP e ao Ministério da Educação e Cultura. Nos anos seguintes, a ele foram associados cincos Centros Regionais, distribuídos pelos Estados de São Paulo, Minas Gerais, Pernambuco, Rio Grande do Sul e Bahia.

Não obstante a ênfase marcadamente sociológica das interpretações, foi nesse contexto que se publicaram os livros O ensino em Minas Gerais no tempo do Império e $O$ ensino em Minas Gerais no tempo da República, de Paulo Krüger Corrêa Mourão (Centro Regional de Pesquisas Educacionais de Minas, CRPE-MG), nos anos de 1959 e 1962. O primeiro livro, contendo 411 páginas, abordava os vários ramos de ensino, apresentando, além da legislação, informações sobre as condições do exercício do magistério, como salários, métodos de ensino e o que denominava curiosidades (castigos físicos e disciplinas), bem como a história dos educandários. O segundo possuía 607 páginas e divergia do antecessor pela inclusão de uma introdução assinada pelo autor, de agradecimentos a autoridades educacionais, dentre elas Abgar Renault, naquele momento diretor-geral do CRPE-MG, de um apêndice rela- 
cionando os estabelecimentos de ensino em funcionamento no ano de 1959 (possível ano de conclusão da obra). Mantinha, entretanto, a mesma organização interna, constituindo o relato por ramos de ensino e pela história de instituições escolares.

Mineiro, formado em engenharia e colaborador assíduo da revista do Instituto Histórico-Geográfico de Minas Gerais, com textos sobre personalidades e fatos históricos, foi, de todos os autores relacionados, o que mais se afastou do primado positivista da mera compilação documental. Não apenas porque emitiu, embora raros, julgamentos ao longo da obra, como comentários sobre o divórcio entre as reformas de 1901 a 1915 e a realidade brasileira, e a consideração do movimento de 1930, como revolução nacional, liderada por Minas, que punha fim à primeira república; como, principalmente, porque permitiu-se a inserção de uma Página de recordação no interior do segundo volume, onde narrou, para quebrar a rigidez fria da História, uma lembrança de sua infância escolar: a inauguração do Grupo Escolar de Diamantina, em 1907, pelo então presidente da Província, João Pinheiro, no qual estudou e sua mãe foi professora ${ }^{58}$.

O investimento na sistematização de fontes e divulgação de documentos para a história da educação não cessou nos anos 1960. Vale ressaltar, aqui, a marca que essa disposição para uma história mais próxima à descrição documental e vazada principalmente na reprodução da fonte legislativa imprimiu, e ainda imprime, em parcela dos trabalhos no campo. Até hoje, o campo elabora guias, índices de legislação e edita a íntegra de leis, no âmbito de uma escrita acadêmica ou como produto da ação de grupos, no esforço sempre renovado de subsidiar a pesquisa. Um exemplo é a Coleção Documentos da Educação Brasileira, iniciativa editorial da recém-criada Sociedade Brasileira de História da Educação (1999), que objetiva disponibilizar o conjunto das Leis e Regulamentos da Instrução Pública das várias Províncias/Estados brasileiros, num total previsto de 80 títulos $^{59}$.

\section{SEGUNDA VERTENTE: A HISTÓRIA DA EDUCAÇÃO E AS ESCOLAS NORMAIS}

Em 1928, era introduzida a disciplina História da Educação no currículo da Escola Normal do Rio de Janeiro. A reorganização do curso de formação para o magistério integrava o conjunto de ações promovidas por Fernando de Azevedo na reformulação da instrução pública do Distrito Federal iniciada em $1927^{60}$. A disciplina surgia no contexto das reformas que, nos anos 1920, pretendiam modificar a educação nacional, introduzindo princípios da escola ativa, posteriormente aglutinados em torno do ideal da escola nova no ensino primário, e elevando o preparo docente pela ampliação e especialização 
do curso normal. Talvez sua introdução curricular tenha sido impulsionada pela onda de artigos avaliativos da instrução pública, editados nos vários jornais brasileiros, em outubro de 1927, por ocasião do centenário da Lei do Ensino Primário no Brasil, numa vaga comemorativa iniciada em 1922, por ocasião dos 100 anos da Independência, aglutinando um conjunto de ações de cunho diverso, realizadas na capital brasileira, como o arrasamento do morro do Castelo e a Exposição Internacional.

Dentre os primeiros professores chamados a ministrar a nova disciplina, no Rio de Janeiro, estava Júlio Afrânio Peixoto. Médico, membro da Academia Brasileira de Letras desde 1911, antigo diretor da Escola Normal do Distrito Federal em 1915, e reformador da instrução pública da capital brasileira em $1916^{61}$, Peixoto foi também o autor do primeiro manual didático brasileiro sobre História da Educação, publicado em 1933 pela Biblioteca Pedagógica Brasileira, na série Atualidades Pedagógicas. No Prefácio a Noções de História da Educação $o^{62}$, anunciava o caráter precursor do livro, ao mesmo tempo que alertava para a eleição de uma "perspectiva panorâmica, a campos microscópicos meramente documentais".

Das 265 páginas da obra, apenas 54 eram dedicadas à educação nacional. As demais abrangiam desde os selvagens e primitivos, passando pelas civilizações antigas, medievais, modernas e contemporâneas, à educação nos Estados Unidos da América e na América Latina. A educação brasileira, apresentada no fim do volume, dividia-se em dois capítulos: Brasil e Escola Nova. Compunha o livro, ainda, um cuidadoso índice onomástico, peça extremamente rara nos trabalhos de história da educação no Brasil. Cada capítulo era iniciado por um sincronismo em que se relacionavam, cronologicamente, os acontecimentos considerados mais relevantes.

Em "Brasil", o texto começava pela análise da educação jesuítica (2 páginas), passava à era pombalina (2 páginas), ao Império (16 páginas) e à República (8 páginas). O tom de elogio às iniciativas dos jesuítas refluía com Pombal, considerado o responsável pela "primeira e desatrosa, como tantas aliás de suas [do Brasil] reformas de ensino". No período imperial, a despeito do alerta efetuado no prefácio, a escrita era recheada de compilações de leis e de excertos de relatórios oficiais, possivelmente colhidos na obra de Pires de Almeida, utilizada como referência. A análise da República mantinha o procedimento anterior, acrescentando-lhe o recurso a estatísticas. Dentre os citados, encontravam-se José Veríssimo e José Bonifácio. Nesses dois períodos, a tônica continuava de crítica. As seis páginas finais do texto eram dedicadas a biografias de educadores brasileiros.

Em todo o capítulo, a forte interferência de Peixoto se fazia sentir pelo uso de ironias e exclamações: "Com o horror nacional ao esforço paciente e custoso, o método chamado ensino mútuo ou lencasteriano sorriu ao Governo" 
$\mathrm{Ou}$, ainda: "Além da fraqueza de vontade, que vai quase ao suicídio 'por omissão', esse [é] outro grande mal nacional, que está a exigir estudos e remédios: a quase ausência de esforço gregário, sinérgico, solidário" ${ }^{4}$. Apropriava-se de fórmulas do regime discursivo jornalístico, recorrentes no período, perceptíveis sob a pena de outros intelectuais, tanto nas matérias publicadas em 1927: " $\mathrm{Pa}$ rece incrível que comemoremos o centenário da oficialização do ensino, no Brasil, com uma percentagem, estimada com otimismo, em 75\% de analfabetos! Já chega a parecer ridículo clamar-se pela solução deste gigantesco problema da educação do povo - tão velho é ele e tão batido são todos os argumentos demonstrativos do crime inqualificável do poder público" "65, quanto em 1922, na comemoração de outro centenário, o da Independência: "É inútil acrescentar qualquer comentário a esses números, desgraçadamente eloquentes demais. Eles mostram, à sociedade, até que ponto descera o desleixo criminoso e frisa nitidamente o espírito pouco progressista dos dirigentes da nação [no Império]" ${ }^{\prime 6}$.

O capítulo seguinte começava pela caracterização dos princípios norteadores da escola nova e pela defesa de seus ideais e propostas. Prosseguia com a enumeração de iniciativas escolanovistas no mundo e concluía afirmando: "A educação, na escola, se resume numa fórmula breve: deve ser o noviciado da sociedade" ${ }^{67}$. A escola nova era apresentada como a possibilidade de reparação desse passado educacional de abandono e escassez de iniciativas no que concerne especialmente à instrução popular.

O texto de Afrânio Peixoto inaugurava uma regra narrativa que iria se instalar como modelo à escrita de manuais brasileiros de História da Educação ${ }^{68}$. As variações tópicas que apresentaram os livros redigidos para uso nas Escolas Normais que o sucederam não chegaram a interferir nesse padrão, que se caracterizava, de acordo com Clarice Nunes, por "deixar de lado a pesquisa em fontes primárias e eleger a compilação comentada como forma de trabalho" ${ }^{\prime 69}$, o que relegava a história da educação à função de explicação das mazelas presentes pelo destaque de aspectos do passado; e "deslocar o eixo [da análise] da organização escolar para o pensamento pedagógico", o que a instaurava como o lugar de defesa de um tipo de educação popular (nesse caso, a escola nova) e um grupo de educadores, seus adeptos, considerados como ponto alto do processo evolutivo das idéias pedagógicas no Brasil e no mundo, porque municiados pelos avanços das ciências, em particular da sociologia e da psicologia (e da medicina higiênica). Essa divisão entre antes e depois da escola nova se instalou nas análises posteriores sobre o passado educacional brasileiro, cristalizando-se em obras de vários educadores, dentre eles Fernando de Azevedo, em sua A cultura brasileira ${ }^{70}$, que veremos mais adiante, e permanecendo como tópica até muito recentemente nos escritos da disciplina.

Nos manuais de história da educação publicados nas décadas seguintes, 
pode-se perceber a reprodução dessa regra narrativa. Das 151 páginas de $P e$ quena história da educação, das madres Francisca Peeters e Maria Augusta de Cooman, editado em $1936^{71}$, apenas 9 referiam-se ao Brasil. Nessas o diagnóstico era o mesmo: a educação popular brasileira ainda estava por iniciar-se. Bento de Andrade Filho, em História da Educação, de 1941 $1^{72}$, chegava a ser mais contundente. A educação no Brasil, ao lado da na América, tomava o lugar da apêndice em seu manual, ocupando 3 páginas das 272 do volume. Era enfático: "educacionalmente, o Brasil não tem, de fato, história. É evidente que, com esta expressão, queremos significar: fatos peculiares a uma história particular" ${ }^{73}$.

Ruy de Ayres Bello publicava em 1945 seu Esboço da história da educação $o^{74}$. Nele, em 25 das 250 páginas, sumariava a educação nacional. Após elogiar os jesuítas, definir a educação pombalina como escuridão, qualificar o ensino mútuo de panacéia e criticar o ato adicional de 1834, retomando assim enunciados de Afrânio Peixoto, valorizava a reforma Francisco Campos de 1931 e a liberdade de ensino religioso por ela implantada. Distinguia-se, aqui, da narrativa de Peixoto, por efetuar um apagamento de referências à escola nova, reflexo de matizes das lutas entre educadores católicos e liberais no campo educacional ${ }^{75}$. Era um dos poucos manuais a indicar a bibliografia utilizada. Dentre os autores citados, destacavam-se Afrânio Peixoto, Bento de Andrade Filho, madres Peeters e Cooman, Primitivo Moacyr e Rocha Pombo.

Lições de história da educação, de Aquiles Archêro Júnior ${ }^{76}$, repetia o padrão. Apenas 43 páginas, de um total de 151, abordavam a educação brasileira. Comentários de Afrânio Peixoto eram reproduzidos como lavra do autor, o que pode ser notado, por exemplo, na crítica realizada a Pombal: "sofreu o Brasil a primeira e desastrosa, como tantas aliás, de suas reformas de ensino" 77 . O mesmo entusiasmo com o movimento escolanovista era revelado, no destaque a educadores, como Lourenço Filho, "incontestavelmente o maior pedagogo do Brasil", e de atos, como o "célebre" Manifesto Educacional de 1932.

Theobaldo Miranda dos Santos, em seu Noções de história da educação, de $1945^{78}$, mantinha o modelo (bem como o título) inaugurado por Afrânio Peixoto. Em 37 páginas, incluídas como Apêndice ao volume com um total de 512 páginas, discorria sobre a educação brasileira. Do destaque inicial à obra jesuítica, comentava a reforma pombalina, que "lavrou a sentença de morte do ensino na Colônia" 79. Um "balanço da obra educacional do Império não apresenta resultados animadores. $O$ ensino era deficiente e fragmentário. As escolas eram escassas, mal organizadas e dirigidas por mestres improvizados" $\mathrm{Na}$ República, "essa situação de marasmo, de rotina e de desequilíbrio devia, entretanto, sofrer modificações acentuadas" ${ }^{\prime \prime}$, devidas ao ambiente revolucionário iniciado com a Guerra de 1914 na Europa, mas estendido até 1930 com a revolução no Brasil. Nesse período mereciam relevo, para o autor, a criação 
da Associação Brasileira de Educação, em 1924, o inquérito sobre instrução pública, realizado para $O$ Estado de S. Paulo, por Fernando de Azevedo, em 1926, as reformas Francisco Campos de Minas Gerais (1927-1930) e Fernando de Azevedo do Distrito Federal (1927-1930), o Manifesto de 1932: todas iniciativas contabilizadas como obras da escola nova, no âmbito do livro $A$ cultura brasileira, de Fernando de Azevedo, publicado em $1943^{82}$. Como bibliografia, além do livro de Azevedo, os trabalhos de Pires de Almeida, Sud Mennucci, Primitivo Moacyr, Afrânio Peixoto, José Veríssimo, Oliveira Santos e madres Peeters e Cooman. Cumpre destacar a reiteração dos autores indicados nas bibliografias, o que nos remete a um repertório de leituras autorizadas na disciplina, demonstrando a permanência de um corpus, que apesar de transitar entre as duas vertentes analisadas, atuava como instância de legitimação de trabalhos em história da educação.

Constituindo-se como exceção, por ser um dos únicos manuais escolares a filiar-se à tradição historiográfica do IHGB, em 1966, veio à luz o livro História da Educação Lusobrasileira, de Tito Lívio Ferreira, publicado pela Editora Saraiva ${ }^{83}$. O autor, dentre outras ocupações, havia sido professor primário e secundário, escrivão de paz, diretor de escola normal e professor de história e sociologia da educação. Havia sido também historiógrafo-chefe da seção de História do Museu Paulista e vice-presidente do Instituto Histórico e Geográfico de São Paulo.

Na apresentação, "em que se explica a razão deste livro" o autor criticava aqueles que faziam história sem atentar para os documentos, entendendo tal produção como literatura, e afirmava que "também o historiador ou historiógrafo não intervém na sociedade humana de outrora nem representa o papel de juiz dos fatos passados em julgado no tempo. Por isso mesmo, em História não há autoridade, há documentos. E a História não existe antes do historiador escrevê-la"s4.

Nas 287 páginas, divididas em 67 pequenos capítulos, e baseados em farta documentação, Ferreira dedicava-se quase exclusivamente à história daquela que ele denominava educação lusobrasileira, ou seja, que se desenvolveu no País de 1559 até a Independência. Além de um refinamento teórico e agudo senso crítico em relação a trabalhos anteriores de história da educação para uso em Escolas Normais, uma inovação substantiva aparecia nesse livro em relação aos demais analisados: em vez de ressaltar a contribuição dos jesuítas à educação no período estudado, o autor fazia depender tal contribuição, em boa parte, do zelo com que a monarquia portuguesa tratava da educação lusobrasileira.

Unia, em parte, a escrita dos manuais de história da educação a relação de seus autores ao pensamento católico. Era o caso das madres Peeters e Cooman, religiosas de Santo André, mas também de Ayres Bello, catedrático de 
filosofia e história da educação e diretor da Escola Normal Oficial de Pernambuco, e Miranda dos Santos, professor do Instituto de Educação, da Faculdade de Filosofia da Santa Úrsula, da Faculdade Católica de Filosofia e do Colégio Sion do Rio de Janeiro, conforme nos indica Nunes ${ }^{85}$. A presença desse etos religioso ${ }^{86}$, em geral católico, na elaboração de manuais de história da educação (mesmo na produção constituída originalmente a partir dos programas de pós-graduação, como veremos adiante) é uma marca até hoje na área (bem como no campo educacional), impregnando-a de uma postura salvacionista, que confere à história da educação não apenas o lugar de compreensão da realidade, mas do desejo de transformá-la ${ }^{87}$.

O fato de serem escritos por educadores, professores e diretores de escolas normais, engajados nas lutas do campo educacional, conferiu-lhes ainda uma outra característica: ser tribuna de defesa de ideais, como já afigurado na análise de Noções de história da educação, de Afrânio Peixoto ${ }^{88}$, mesclando na escrita da história, para os tempos mais recentes, depoimentos da vivência do autor na arena educativa elevados ao estatuto de análise historiográfica (um procedimento que reencontraremos em A cultura brasileira, de Fernando de Azevedo ${ }^{89}$ ).

Concorreu para reforçar as tendências anteriores, a associação que se foi produzindo entre a história da educação e a filosofia da educação, ou integradas em uma única disciplina curricular ou partilhando das diretrizes de uma mesma seção ou departamento, no âmbito das escolas de formação para o magistério. Se em 1928, na gestão Fernando de Azevedo da instrução pública carioca, tal vinculação não era prevista para a Escola Normal do Distrito Federal, sendo história da educação ministrada apenas no quinto ano, ao lado de sociologia, higiene, puericultura, didática, pedagogia e trabalhos manuais; já em 1932, com a reorganização promovida por Anísio Teixeira e a transformação dessa escola em Instituto de Educação, passava a integrar a segunda seção, História e Filosofia da Educação, Educação Comparada e Administração escolar ${ }^{90}$. A criação do curso de Pedagogia na Faculdade Nacional de Filosofia, em $1939^{91}$, e lei orgânica para o ensino normal, de 1946, unificando as matérias do segundo ciclo do curso para todo o Brasil, incluindo história e filosofia da educação como uma única disciplina ministrada na terceira série $^{92}$, vieram a consagrar o modelo. Essa integração reforçou o afastamento da escrita da história da educação da prática dos arquivos, estimulando as interpretações que pretendiam conferir-lhe uma importância moral.

Constituída como disciplina escolar, em geral em proximidade com a filosofia da educação, impregnada de uma postura salvacionista e tribuna de defesa de um ideal de educação popular, à história da educação foi delegado o lugar de ciência auxiliar da Pedagogia. Sua função era, no dizer de Mirian Warde, "responder à necessidade de os futuros professores cogitarem do dever ser 
educacional, dos valores humanos mais elevados a serem preservados e despertados pela prática da Educação" ${ }^{\prime 93}$, o que a transformava, menos em uma ciência matricial, como a sociologia, a psicologia ou a biologia, e mais em uma disciplina formadora. Nascia, portanto, "para ser útil e para ter sua eficácia medida não pelo que é capaz de explicar e interpretar dos processos históricos objetivos da Educação, mas pelo que oferece de justificativas para o presente" (idem, ibidem $)^{94}$. Era a expressão do que Mirian Warde denominou pragmatismo moral e do que Clarice Nunes chamou "permanência dos valores de uma civilização cristã ${ }^{\prime \prime 5}$.

Dessa maneira, apesar da crítica que Afrânio Peixoto efetuou aos trabalhos da disciplina, no prefácio ao livro de Primitivo Moacyr, já em 1936 (e talvez a seu próprio manual, publicado três anos antes) - "No Brasil não se pesquisa. Todos tiramos de nós a substância de nossos escritos. A história nessas condições é repetição, é comentário, é fantasia interpretativa" —, citada anteriormente; nos manuais de história da educação para uso nas Escolas Normais, salvo a contribuição de Tito Lívio Ferreira, a história continuou como repetição e comentário (e, muitas vezes, como fantasia interpretativa).

\section{TERCEIRA VERTENTE: A HISTÓRIA DA EDUCAÇÃO E A ESCRITA ACADÊMICA ${ }^{96}$}

A convite da Comissão Censitária Nacional, Fernando de Azevedo elaborou A cultura brasileira ${ }^{97}$, como volume introdutório aos resultados do Recenseamento Geral de 1940. Publicado em 1943 pela Imprensa Nacional, o livro, com suas quase 800 páginas, divididas em três tomos (Os fatores da cultura, A cultura, A transmissão da cultura) e fartamente ilustrado com fotografias, superou largamente a encomenda e constituiu-se em obra de referência para o campo educacional, mais especificamente no que tange ao terceiro tomo, onde o objeto central eram os processos educativos.

Criada com o propósito de "acompanhar, sob todos os seus aspectos, a evolução do povo e a formação da comunidade e vida nacional em mais de 400 anos de sua história" ${ }^{\prime \prime}$, A cultura brasileira teve sua escrita marcada pela dupla inserção de Fernando Azevedo. Professor universitário, lente de sociologia educacional, em 1942, e de sociologia, em 1943, da Faculdade de Filosofia, Ciências e Letras (USP), da qual foi também diretor, entre 1941 e 1943 (período de redação da obra), Azevedo fora reformador da instrução pública do Distrito Federal (1927-1930) e de São Paulo (1933), redator do Manifesto dos pioneiros da educação nova, carta-monumento publicada em 1932 defendendo um modelo de educação nacional (a escola nova), e presidente da Associação Brasileira de Educação, eleito em 1938.

A obra inseria-se, assim, por um lado, no rol de estudos acadêmicos que 
nos anos 1930 tendiam a compreender e produzir identidades para a cultura nacional (o que explica a redação dos dois primeiros tomos), tal como Raizes do Brasil (1936), de Sérgio Buarque de Holanda ${ }^{99}$, e Casa-grande e senzala (1933), de Gilberto Freyre ${ }^{100}$ : ambos, aliás, devidamente citados por Azevedo. Sérgio Buarque de Holanda autorizava-o a enfatizar o significado da herança portuguesa na conformação da cultura: "De Portugal nos veio a forma atual de nossa cultura: o resto foi matéria plástica que se sujeitou, bem ou mal, a essa forma" ${ }^{\prime 101}$. Freyre permitia-lhe afirmar que a religiosidade peculiar disseminada nestas terras, "doméstica, lírica e festiva, de santos compadres, de santas comadres dos homens, de Nossa Senhora madrinha dos meninos" ${ }^{102}$, marcara a identidade brasileira, distinguindo-a de outras como a norte americana ${ }^{103}$.

Inseria-se também, A cultura brasileira, no campo de lutas da educação brasileira, erigindo-se em plataforma de defesa de um ideal de escola, a escola nova (objetivo mais claramente delineado no terceiro tomo), numa tradição que remontava a Afrânio Peixoto e a seu Noções de história da educação ${ }^{104}$. Mas o sobrepujava, posto que mais que obra de divulgação do pensamento escolanovista, como era o texto de Peixoto, o livro de Azevedo almejava ser (e foi por muito tempo) lugar de produção de uma memória sobre o movimento da escola nova no Brasil.

Segundo Marta Carvalho, "alternando procedimentos de condensação e esvaziamento de sentido, a narrativa de Azevedo vai compondo os seus personagens ${ }^{\prime 105}$ e instituindo heróis e vilões da história da educação brasileira. No primeiro caso, encontravam-se os jesuítas e os pioneiros da educação nova. No segundo, estavam Pombal, o ato de 1834 e os educadores tradicionais. Utilizando-se de um discurso bipolar, Azevedo desenhava o novo, associado aos reformadores de 1920 e 1930, em oposição ao velho, forças reacionárias de pensamento educacional, e construía a história da educação como um movimento ascensional em direção ao novo, à renovação do sistema educativo ${ }^{106}$. Estavam assim delineadas as duas ênfases da análise de Azevedo: a história das idéias e dos projetos pedagógicos e a história da organização dos sistemas de ensino. Sujeito da narrativa e do jogo político em que se disputavam os projetos de uma educação nacional no âmbito do recém-criado Ministério da Educação e Saúde (1930), Fernando de Azevedo transformava-se a si mesmo em herói, e sua trajetória profissional e pessoal, em fonte. Ao relatar as inovações realizadas nas décadas de 1920 e 1930 no Brasil, erigia a "memória dos renovadores [...] em conhecimento histórico" 107 .

A escrita de A cultura brasileira recebeu ainda uma outra marca: a experiência jornalística de Azevedo. Integrante de uma intelectualidade que nos anos 1920 (e até os anos 1960) se utilizava prioritariamente do jornal para difusão de idéias e propostas - na qual se incluíam Sérgio Buarque de Holan- 
da, colaborador d'O jornal, no Rio de Janeiro, e Gilberto Freyre, do Diário de Pernambuco, e muitos outros como Cecília Meirelles, Diário de Notícias, e Sud Mennucci, O Estado de S. Paulo (e mesmo Afrânio Peixoto que escrevia para diversos diários cariocas) - Fernando de Azevedo, entre 1917 e 1922, foi jornalista do Correio Paulistano, e entre 1923 e 1926, atuou como redator d'O Estado de S. Paulo, sendo responsável pelo inquérito sobre "Instrução Pública”, em 1926. Ao longo de todos esses anos de trabalho constituiu um estilo de escrita cujas estratégias de enunciação (e convencimento) se organizavam pelas regras da linguagem jornalística. Repetições, polaridades, emissão de julgamentos e ironias, ainda que veladas, formavam parte dos agenciamentos típicos desse discurso.

Traduzida em 1950 para o inglês e desde de 1976 desmembrada, ganhando o terceiro tomo (A transmissão da cultura) estatuto de livro independente, a obra tornou-se referência necessária no campo educacional e na área da história da educação, conforme destacaram Zaia Brandão ${ }^{108}$ e Marta Carvalho ${ }^{109}$. Contribuíram para esse prestígio acadêmico não apenas a extensão de suas análises e o volume de informações coligidas (apesar de não freqüentar arquivos, Azevedo levantou um grande conjunto de dados e fotografias, com a colaboração de amigos), mas também a permanência de Azevedo como professor universitário na FFCL-USP até sua aposentadoria em 1961, formando novos quadros, influenciando a elaboração de trabalhos e redigindo outras obras. De acordo com depoimento de Tirsa Peres ${ }^{110}$, até o fim dos anos 1950, era nos cursos de Sociologia, de Azevedo, que a história da educação brasileira se explorava, especialmente no que concernia à atuação do próprio Azevedo como reformador da instrução pública do Distrito Federal e de São Paulo. Sua importância também se deveu à proeminência do autor no campo político da educação nacional. Nos anos seguintes à publicação de A cultura brasileira, Fernando de Azevedo assumiu a Secretaria de Educação de São Paulo, em 1947; dirigiu a Biblioteca Pedagógica Brasileira, da Cia. Editora Nacional, até 1946; foi diretor do Centro Regional de Pesquisas Educacionais de São Paulo, de 1956 a 1961; e redator do Manifesto de 1959 (Mais uma vez convocados). A vasta coleção de cartas depositadas no Arquivo Pessoal Fernando de Azevedo, do Instituto de Estudos Brasileiros (USP), oferece elementos tanto para a percepção dessa rede efetuada para a recolha de fontes à escrita d' $A$ cultura brasileira, quanto das articulações políticas em torno da educação nacional, nas quais esteve Azevedo envolvido ${ }^{111}$.

No âmbito da Universidade de São Paulo, outros trabalhos voltados especificamente para a área de história da educação surgiram, inicialmente no Departamento de Pedagogia da FFCL (1938-1969), e posteriormente no Centro Regional de Pesquisas Educacionais (1956-1974) e na Faculdade de Edu- 
cação (1969). Articulavam-se especialmente em torno da cátedra de História e Filosofia da Educação (FFLC-USP), regida por Laerte Ramos de Carvalho ${ }^{112}$. Assistente desde 1948, Ramos de Carvalho assumiu-a como titular em 1952, quando defendeu a tese As reformas pombalinas da instrução pública, resultado de pesquisas realizadas em acervos portugueses (transformada em livro apenas em 1978$)^{113}$.

A tese centrava-se em um tema de interesse à historiografia portuguesa, mas pouco explorado pela historiografia educacional brasileira, que reduzira Pombal a signo de desestruturação da obra educativa jesuítica. Voltava-se para o levantamento de fontes primárias e procedia a um estudo histórico que buscava compreender a educação no seu "sentido intimo, a filosofia" ${ }^{14}$. Dessa maneira, Ramos de Carvalho operava distanciamentos ao propósito de uma interpretação sociológica da cultura brasileira enunciado por Azevedo, ao mesmo tempo que retomava princípios da vertente associada ao IHGB (40 páginas de Apêndice reproduziam documentos inéditos localizados em Portugal), ainda que fizesse críticas ao trabalho de Primitivo Moacyr, considerado como "um repositório de documentos" 115 , e se inseria na linhagem que unia história e filosofia como matrizes do entendimento do passado educacional, possibilitado pelo conhecimento "dos ideais pedagógicos" 116.

Como assistentes à cátedra, Ramos de Carvalho convidou dois alunos, João Eduardo Rodrigues Villalobos e Roque Spencer Maciel de Barros ${ }^{117}$, compondo o núcleo inicial de um grupo de pesquisadores que, nos anos 1960, seria ampliado pelo crescimento dos Institutos Isolados de Ensino Superior no Estado de São Paulo, aglutinando nomes como Heládio César Gonçalves Antunha, José Mario Pires Azanha e Maria de Lourdes Mariotto Haidar, da Pedagogia-USP, Casemiro Reis Filho da FFCL de Rio Preto, Rivadávia Marques Júnior, Jorge Nagle e Tirsa Regazzini Péres da FFCL de Araraquara e posteriormente Maria Aparecida Rocha Bauab (Rio Preto), Maria da Glória de Rosa (Marília) e Miriam Xavier Fragoso (Assis), dentre outros, de acordo com o depoimento de Leonor Tanuri ${ }^{118}$, também integrante do grupo.

A partir de um plano geral de monografias traçado por Ramos de Carvalho, e com base em documentação primária, cada pesquisador dedicava-se a investigar um tema ou personagem do passado educacional brasileiro, objetivando compor um quadro histórico compreensivo dos séculos XVIII a XX. Assim, foram elaborados, dentre outros, os trabalhos: A ilustração brasileira, de Roque Barros (1959), Educação e sociedade no Brasil, de Jorge Nagle (1966), A reforma de 1920 da instrução pública no Estado de São Paulo, de Antunha (1967), O ensino secundário no Império, de Mariotto Haidar (1971), e A Escola Normal no Estado de São Paulo, de Leonor Tanuri (1973). Como resultados da pesquisa de campo encetada pelo grupo, levantamentos de produção bibliográfica e de documentação de interesse à educação brasileira em arquivos 
e bibliotecas passaram a circular, inicialmente sob forma mimeografada e depois impressa, como o Índice básico da legislação do ensino paulista (18901945), de Casemiro Reis Filho (1963), e o Ensino Normal em São Paulo (18461963): inventário de fontes, de Maria Aparecida dos Santos Rocha (1973), para citar apenas dois.

A partir dos 1960 a história da educação brasileira passou a ser incluída de forma mais significativa no programa geral da cátedra, talvez como fruto dos estudos do grupo ${ }^{119}$. Talvez em razão do estímulo dado pelo parecer do Conselho Federal de Educação (CFE 251/62), que especificava que o currículo mínimo dos Cursos de Pedagogia deveria contar com a disciplina história da educação, "entendida como uma apreciação coerente dos fundamentos históricos que explicam a educação moderna, e, dentro desta orientação, conterá uma divisão especial dedicada à História da Educação Brasileira" ${ }^{120}$. Talvez ainda, em virtude da aposentadoria de Azevedo, em 1961.

A produção desse grupo esboçou, segundo Mirian Warde, "um projeto de construção de uma história da educação brasileira autônoma, apoiada em levantamentos documentais originais, capaz de recobrir o processo de desenvolvimento do sistema público de ensino"121. E se desenrolou, de acordo com Monarcha, ${ }^{122}$ dentro dos cânones do realismo histórico, configurando o que denominou de "atos inaugurais" da história da educação brasileira em São Paulo, por propiciar a formação de uma mentalidade histórica em educação através de "sedimentação e divulgação de uma metodologia privilegiada; profissionalização de um tipo de autor: o professor universitário; delimitação de um objeto de estudo e conhecimento e constituição de um público leitor específico".

No bojo desse processo, Ramos de Carvalho divulgou, em 1971, o artigo "A educação brasileira e sua periodização", no volume mimeografado resultante do I Seminário de Estudos Brasileiros - Encontro Internacional de Estudos Brasileiros, realizado no IEB-USP, em que criticava o uso da história política e administrativa brasileira como marco para a história educacional. Afirmava: “À medida que nos aprofundamos na análise de nosso passado educacional, mais se nos reforçam as convicções sobre a inadequação deste modelo tradicional de periodização para a compreensão da história da escola brasileira"123.

À liderança acadêmica do grupo Laerte Ramos de Carvalho havia associado uma liderança política, sendo sucessivamente diretor do Centro Regional de Pesquisas Educacionais de São Paulo, entre 1961 e 1965 (substituindo, portanto, Azevedo na função), diretor do Departamento de Educação da FFCLUSP, entre 1963 e 1965, reitor da Universidade de Brasília, entre 1965 e 1967, e primeiro diretor da Faculdade de Educação-USP, em $1969^{124}$, o que, por certo, deu-lhe a oportunidade de ter apoio institucional e político para assegurar a perenidade desse projeto de "construção de uma história da educação brasileira autônoma", e seu lugar de "ato inaugural" de uma historiografia 
educacional paulista. Permitiu-lhe, também, a manutenção de um viés liberal de análise nos estudos históricos em educação, a despeito do crescimento da influência da teoria marxista, propiciado pela criação dos programas de pósgraduação em Educação no País, nos anos 1960 (ainda que durante os anos 1970, interpretações de matiz marxista tenham surgido na pós-graduação da Faculdade de Educação da USP, instalada em 1971).

Se a escrita dessa geração de pesquisadores associados à cátedra não revelava os mesmos agenciamentos do traço azevediano nem a mesma matriz sociológica da análise, privilegiando um aporte filosófico, seus autores se aproximavam de Azevedo pela defesa de uma proposta de educação nacional muito semelhante. Liberais, esses intelectuais, no que diz respeito a Ramos de Carvalho, Villalobos e Maciel de Barros, concebiam a escola como um direito de todos e um dever do Estado e acreditavam que a promoção social pela escolarização era a via pacífica para a equalização das diferenças sociais e econômicas, partilhando de um ideal meritocrático de organização social. Compuseram com Azevedo a "Campanha em Defesa da Escola Pública" e assinaram o Manifesto de 1959 (que ostentava o título Mais uma vez convocados em referência explícita ao manifesto de 1932 em prol da escola nova), ambos lançados no conjunto das discussão da elaboração da primeira Lei de Diretrizes e Bases da Educação Nacional.

O surgimento dos programas de pós-graduação em Educação no fim dos anos 1960 e início dos anos 1970, como dito acima, alterou a configuração dos trabalhos na disciplina, menos por um afastamento dos primados da relação entre história e filosofia e mais, ao contrário, por uma ênfase nessa aproximação a partir de um referencial teórico-marxista, apoiado primeiramente em Althusser (fim dos anos 1960 e 1970) e depois em Gramsci (anos 1970 e 1980). Os primeiros programas instalaram-se nas universidades católicas, PUC-Rio (1965) e PUC-SP (1969), e aglutinaram uma geração de acadêmicos "diretamente vinculada à Igreja Católica ou gravita[ndo] na sua esfera de influência" 125 , constituindo-se no lugar de confluência entre o pensamento marxista e a nova pregação da Igreja, exposta nas Conferências do Conselho Episcopal Latinoamericano de Mendelin (1969) e Puebla (1979), e condensada na fórmula da "opção pelos pobres".

Manifestando um forte engajamento político na luta contra a ditadura militar (1964-1984), essa nova intelectualidade não chegou a romper com uma matriz azevediana de escrita da história da educação brasileira, mas a ela se acomodou, acentuando a centralidade à ação política dos intelectuais e ao conceito ampliado de Estado, o que denotava o modo particular como Gramsci foi apropriado por essa geração, segundo Mirian Warde e Marta Carva$\mathrm{lho}^{126}$. Assim, como "Azevedo [havia] pensado: sujeitos conscientes dos problemas sociais (educacionais em particular) poderiam intervir de fora para dentro 
da história reorientando seu rumo", essa intelectualidade acreditava que "a legitimidade dessa intervenção seria conferida pelo acerto da leitura social e política da qual os intelectuais seriam portadores; a sua eficácia medida pela capacidade de reorientar as ações da sociedade política sobre a sociedade civil"127. Para Luís Carlos Barreira ${ }^{128}$, os aspectos que chamavam mais a atenção na produção inicial dos programas de pós-graduação eram "a abordagem dialética associada ao veio teórico da dependência, a importância metodológica atribuída ao contexto e o peso exercido pelas determinações econômicas". Os trabalhos recorriam, em geral, a documentos impressos, primando pelo estudo da legislação ${ }^{129}$. Os eixos da análise oscilavam entre as idéias pedagógicas e a organização do sistema público de ensino: temas presentes na historiografia educacional brasileira desde os primeiros textos do século XIX.

Voltada a explicar o presente e nele intervir, essa historiografia confirmou o pragmatismo já identificado por Mirian Warde para os anos 1930 e 1940, consolidando uma escrita da história da educação presa ao que a autora denominou de presentismo pragmatista ${ }^{130}$. Muitos dos primeiros estudos elaborados no interior desses programas de pós-graduação chegaram aos cursos de formação de professores, em nível secundário ou superior, e aí foram difundidos como manuais escolares. A vinculação ao pensamento religioso (e o engajamento político) por parte de vários dos seus autores fez com que mantivessem a postura salvacionista, identificada por Eliane Marta T. Lopes e Ana Galvão ${ }^{131}$, para os manuais que os haviam antecedido, manifestando " $a$ fé na educação como símbolo de poder de intervenção no domínio das consciências", como afirmou Clarice Nunes ${ }^{132}$.

\section{COMENTÁRIOS FINAIS}

Se, em 1984, Mirian Warde apontava a fragilidade dos programas de pósgraduação e a pequena tradição de estudos na área como fatores constitutivos do pragmatismo presente nas teses e dissertações analisadas, o fortalecimento dessas instituições ao longo das duas últimas décadas parece ter repercutido favoravelmente na produção da área. Indícios disso podem ser percebidos na criação, na década de 1980, e manutenção até hoje de Grupos de Trabalho de História da Educação. Em 1984, no interior da principal instituição científica da área, a ANPEd (Associação Nacional de Pós-Graduação e Pesquisa em Educação) e utilizando muito positivamente desse lugar e do apoio institucional auferido, surgia o GT História da Educação que rapidamente tornou-se o principal espaço nacional de aglutinação de pesquisadores, de crítica historiográfica e de difusão de novos horizontes de investigação na área, como a história das mentalidades, o (pós-)estruturalismo e a história 
cultural, "estendendo sua influência para vários centros de ensino e pesquisa brasileiros" 133 .

Em 1986 era criado o Grupo de Estudos e Pesquisas História, Sociedade e Educação no Brasil, conhecido pela sigla HISTEDBR. Com sede na Universidade de Campinas, articulava mais de duas dezenas de outros grupos em quase todos os Estados brasileiros e realizava reuniões periódicas para discussão dos resultados de suas pesquisas. Segundo o coordenador geral do HISTEDBR, Dermeval Saviani, em conferência pronunciada no IV Seminário Nacional de Estudos e Pesquisas História, Sociedade e Educação no Brasil, ocorrido em 1997, o grupo "surgiu, como sugere o seu nome, com a preocupação de investigar a História da Educação pela mediação da Sociedade, o que indica a busca de uma compreensão global da educação e seu desenvolvimento. Contrapunhase, pois, à tendência que começava a invadir o campo da historiografia educacional" 134 . Tal "tendência" acima referida é, nas produções do grupo, constantemente associada ao "paradigma pós-moderno" e à história cultural, e sua recusa afirma um viés marxista de análise histórica.

Ao longo dos anos de 1990, a par de um incremento das ações do GT de História da Educação e do HISTEDBR, a área se viu enriquecida com a constituição de inúmeras outras instâncias de aglutinação de pesquisadores e condensação/difusão de perspectivas teórico-metodológicas. A primeira grande novidade foi, ao que nos parece, uma mudança substantiva na forma própria de organizar e realizar as pesquisas: além da continuidade da tradição das investigações efetuadas individualmente, emergiu na área, como em todo o campo da educação, uma multiplicidade de grupos de pesquisa que se impuseram o desafio de investigações de escopo alargado, de longo prazo e com grande preocupação com o mapeamento, organização e disponibilização de acervos documentais ${ }^{135}$.

Assistimos, também, à organização de associações científicas específicas da área, que se constituíram órgãos de divulgação impressa. Em 1996, os pesquisadores em história da educação do Rio Grande do Sul, decidiram, pioneiramente, criar a Associação Sul-Rio-Grandense de Pesquisadores em História da Educação/ASPHE ${ }^{136}$, responsável pela publicação História da Educação. Em 1999, foi a vez da criação da Sociedade Brasileira de História da Educação(SBHE), fruto de um trabalho de cooperação e articulação dos diversos pesquisadores e grupos de pesquisas atuantes na área, e da Revista Brasileira de História da Educação. Houve também, no período, o crescimento do intercâmbio com pares de outros países, notadamente Portugal e França, através da realização de congressos (lusobrasileiros e iberoamericanos); de programas de doutoramento e pós-doutoramento em universidades estrangeiras, bem como da vinda de pesquisadores internacionais ao Brasil.

Outra constação de Mirian Warde, em 1984, era a relativamente pobre 
interlocução da história da educação com outras áreas disciplinares — com a história, economia e sociologia, sobretudo - , sustentada pelo "fato de que a maioria dos trabalhos não reflete o acompanhamento dos debates que se travam e dos avanços que se realizam no campo dos estudos históricos em termos de novas referências explicativas" 137 . Hoje pode-se afirmar o contrário, chamandose a atenção para o alargamento da interlocução com uma variada gama de disciplinas acadêmicas - sociologia, lingüística, literatura, política, antropologia, geografia, arquivística - , bem como para o fato de a história da educação ser, ao mesmo tempo, uma subárea da educação e uma especialização da história. Para os historiadores da educação isto tem significado uma forma de marcar o seu pertencimento à comunidade dos historiadores, e uma maneira de reafirmar a identificação de suas pesquisas com procedimentos próprios ao fazer historiográfico, o que, sem dúvida, vem se afirmando como diferença à prática enraizada nas Escolas Normais e às preocupações forjadas na aproximação com a Filosofia (ainda que a separação destes dois campos de conhecimento não se tenha operado completamente e seja objeto de disputa entre grupos no interior da comunidade de historiadores da educação).

No âmbito dos estudos históricos, um número relativamente extenso de perspectivas teórico-metodológicas parece influenciar os trabalhos. De acordo com Catani e Faria Filho, em análise dos trabalhos apresentados no GT da ANPEd, entre 1984 e 2000, "ao ser empreendido o exame quantitativo da bibliografia, verificou-se que as referências numericamente superiores são feitas a P. Bourdieu, R. Chartier, M. Foucault, J. Le Goff, M. de Certeau e K. Marx"138. Indicam que há diversas maneiras de fazer história da educação. Nesse sentido, investigar as formas como pesquisadores têm dialogado com as várias correntes historiográficas, como marxismo, história cultural, história das mentalidades ou o estruturalismo (e pós-estruturalismo) pode apontar tanto para permanências quanto para acomodoções da historiografia educacional a novos referenciais analíticos. Uma história das apropriações a que essas matrizes teóricas estiveram e estão sujeitas no âmbito da pesquisa em história da educação no Brasil, nos últimos trinta anos, poderia trazer, sem dúvida, uma grande contribuição ao entendimento dos intercâmbios e aproximações, bem como das lutas e apagamentos que tornaram, e tornam possível atualmente falar num campo de produção em história da educação em nosso país.

Por fim, um alerta. Michel de Certeau ${ }^{139}$, ao discorrer sobre a operação historiográfica, sugere a existência de um conjunto (por vezes tácito) de regras de enunciação no campo, constituídas por e constituintes de um corpo de sujeitos que nele transitam. Forçoso é então assumir que, partícipes da construção da disciplina História da Educação, nós, os autores, somos, nos momentos mais recentes, sujeitos e objetos desta narrativa. E, mais do que isso, que as fontes que utilizamos são, elas também, peças do jogo político que 
institui a memória (e produz o esquecimento) nas constantes lutas de representaçã o ${ }^{140}$ travadas no interior do campo.

\section{NOTAS}

${ }^{1}$ Os autores agradecem a leitura atenciosa dos originais e as sugestões de Maria Lúcia Spedo Hilsdorf.

${ }^{2}$ Diana Gonçalves Vidal é professora de História da Educação da Faculdade de Educação da USP e uma das coordenadoras do Centro de Memória da Educação dessa mesma faculdade. Atualmente assume a vice-coordenadoria do Grupo de Trabalho de História da Educação da Associação Nacional de Pós-Graduação e Pesquisa em Educação. Entre 1999 e 2001, atuou como secretária da Sociedade Brasileira de História da Educação em sua primeira diretoria.

${ }^{3}$ Luciano Mendes de Faria Filho é professor de História da Educação da Faculdade de Educação da UFMG e coordenador do Grupo de Estudos e Pesquisas em História da Educação dessa mesma faculdade. Entre 1997 e 2001, foi coordenador do Grupo de Trabalho de História da Educação da Associação Nacional de Pós-Graduação e Pesquisa em Educação.

${ }^{4}$ WARDE, Mirian Jorge. "Anotações para uma Historiografia da Educação Brasileira”. In Em Aberto, ano 3, n. ${ }^{\circ 23}$, set./out. 1984; ___ . “Contribuição da História para a Educação”. In Em aberto, ano IX, n. ${ }^{\circ}$ 47, jul. set. 1990, pp. 3-11; e BARREIRA, Luís Carlos. História e historiografia. As escritas recentes da história da educação brasileira (1971-1988). Doutorado, Faculdade de Educação, UNICAMP, 1995.

${ }^{5}$ XAVIER, Libânea Nacif. "Particularidades de um campo disciplinar em consolidação: balanço do I Congresso Brasileiro de História da Educação (RJ/2000)”. In: Sociedade Brasileira de História da Educação (org.). Educação no Brasil. Campinas: SBHE \& Autores Associados, 2001.

${ }^{6}$ NUNES, Clarice. "Ensino e historiografia da educação: problematização de uma hipótese”. In Revista brasileira de educação, n. ${ }^{\circ}$ 1, jan.- abr. 1996, pp. 67-79; ALVES, Cláudia Costa. "Os resumos das comunicações e as possibilidades esboçadas no II Congresso LusoBrasileiro de História da Educação”. In CATANI, Denice \& SOUZA, Cynthia Pereira de (orgs.). Práticas educativas, culturas escolares, profissão docente. São Paulo: Escrituras, 1998; VEIGA, Cynthia G. \& PINTASSILGO, Joaquim. Pesquisas em história da educação no Brasil e em Portugal: caminhos da polifonia. Belo Horizonte/Lisboa, 2000, 17p. Impresso.

${ }^{7}$ CATANI, D. Bárbara \& FARIA FILHO, Luciano Mendes de. "Um lugar de produção e a produção de um lugar: a história e a historiografia divulgadas no GT História da Educação da ANPEd (1985-2000)”. Revista Brasileira de Educação, 19, jan./abr. 2002, pp. 113128; BASTOS, Maria Helena \& BENCOSTA, Marcus Levy \& CUNHA, Maria Teresa S. Uma cartografia da pesquisa em história da educação na Região Sul: Paraná, Santa Catarina e Rio 
Grande do Sul (1980-2000). Trabalho encomendado pelo GT História da Educação da ANPEd, mimeo, 2002.

${ }^{8}$ SAVIANI, Dermeval. "O debate teórico e metodológico no campo da história e sua importância para a pesquisa educacional”. In SAVIANI, Dermeval \& LOMBARDI, José C. \& SANFELICE, José L. (orgs.) História e história da educação: o debate teórico-metodológico atual. Campinas: Autores Associados/HISTEDBR, 1998, pp. 7-15; \& LOMBARDI, José C. "Grupo de Estudos e Pesquisas História, Sociedade e Educação no Brasil (HISTEDBR): histórico e situação atual”. Educação em Revista, n.o 34, dez./2001, pp. 135-146.

${ }^{9}$ De maneira sistemática, dois grupos de investigadores vêm-se dedicando à temática: um na PUC-SP, sob a coordenação de Mirian Jorge Warde, e outro, na UFF, sob a coordenação de Clarice Nunes. Ambas as pesquisas contam com financiamento do CNPq, e algumas das publicações decorrentes do trabalho de campo foram referenciadas na bibliografia deste artigo.

${ }^{10}$ DE CERTEAU, M. A escrita da história. Rio de Janeiro: Forense Universitária, 1982. Desde já alertamos para o caráter parcial dessa revista, em razão dos limites impostos tanto pela escassez de pesquisas sobre o tema quanto pelo formato de "artigo", que implica o equacionamento da discussão em um número reduzido de páginas.

${ }^{11}$ DE CERTEAU, M. Op. cit.

${ }^{12}$ PEETERS, Madre Francisca \& COOMAN, Madre Maria Augusta. Pequena história da educação. São Paulo: Cia. Melhoramentos, 1936.

Nem todas as obras que preenchiam tal condição, entretanto, foram aqui abordadas.

${ }^{13}$ AZEVEDO, Fernando de. A cultura brasileira. Introdução ao estudo da cultura no Brasil. São Paulo: Melhoramentos, 1958, 3ª edição.

${ }^{14}$ DE CERTEAU, M. Op. cit.

${ }^{15}$ SANTA-ANNA Nery, Frederico José de. “L'instruction publique au Brésil”. In Revue Pédagogique, n. ${ }^{\circ}$ 9, t. V, juil.déc. 1884, pp. 204-24.

${ }^{16}$ KUHLMANN JR., Moysés. “Raízes da historiografia educacional brasileira (1881-1922)”. In Cadernos de Pesquisa, n. ${ }^{\circ}$ 106, mar.1999, pp.159-172, p. 160.

${ }^{17}$ Os dados biográficos do autor foram recolhidos principalmente em: MAIOR, Mário Souto. Dicionário dos Folcloristas Brasileiros. Goiânia: Kelps Editora, 2000.

${ }^{18}$ SANTA-ANNA Nery, Frederico José de. O país das Amazonas. Tradução, Ana Mazur Spira; apresentação, Mário Guimarães Ferri. Belo Horizonte: Livraria Itatiaia Editora; São Paulo: Editora da Universidade de São Paulo, 1979.

${ }^{19}$ SANTA-ANNA Nery, Frederico José de. Folclore brasileiro. $2^{\text {a }}$. ed. Série Estudos e pesquisas, 80. Trad. Vicente Sales. Recife: Fundaçao Joaquim Nabuco, Editora Massangana, 1992, 235 pp.

${ }^{20}$ KUHLMANN JR., Moysés. Op. cit., p. 162. 
${ }^{21}$ Idem.

No ano de 1889, houve ainda a republicação, em separado, do verbete "Le Brésil" da enciclopédia de Émile Levasseur, no qual se inclui o capítulo "L’instruction”, por Levasseur e pelo barão do Rio Branco, por iniciativa do Sindicato Franco-Brasileiro para a Exposição Universal de 1889.

${ }^{22}$ PIRES DE ALMEIDA, José Ricardo. Instrução pública no Brasil (1500-1889). História e legislação. São Paulo: EDUC, 2000, p. 17.

Em 1989, na comemoração do centenário de sua edição, a obra de Pires de Almeida foi traduzida para o português por Antônio Chizzotti e publicada pela Editora da PUC-SP em conjunto com o Instituto Nacional de Estudos Pedagógicos (INEP), na série "Memória da Educação Brasileira”. Dez anos depois foi republicada pela EDUC e INEP, agora na série "Publicações de fontes de informação em Educação". Esta última foi a versão utilizada para a elaboração do presente artigo.

${ }^{23}$ NUNES, Clarice. "A instrução pública e a primeira história sistematizada da educação brasileira”. Cadernos de Pesquisa, n. ${ }^{\circ}$ 93, maio 1995, pp. 51-59, p. 56; GONDRA, José Gonçalves. "Sem Deus nem Rei? O positivismo na escrita da educação brasileira". Revista Brasileira de Estudos Pedagógicos, v. 77, n. ${ }^{\circ}$ 185, jan./abr. 1996, pp. 169-190, p. 179 e KUHLMANN JR., Moysés. Op. cit., p. 164.

${ }^{24}$ PIRES DE ALMEIDA, José Ricardo. Op. cit., p. 41.

${ }^{25}$ NUNES, Clarice. "A instrução pública e a primeira história sistematizada da educação brasileira”. Op. cit., p. 56.

${ }^{26}$ Idem., p. 53.

${ }^{27}$ GONDRA, José Gonçalves. “Sem Deus nem Rei? [...]”. Op. cit., p. 172.

${ }^{28}$ NUNES, Clarice. "A instrução pública e a primeira história sistematizada da educação brasileira”. Op. cit., p. 54.

${ }^{29}$ PIRES DE ALMEIDA, José Ricardo. Op. cit.., p. 307.

${ }^{30}$ RODRIGUES, José Honório. A pesquisa histórica no Brasil. Brasiliana: série grande formato. São Paulo: Cia Editora Nacional; Brasília: INL, 3ª edição, 1978, p. 37.

${ }^{31}$ GUIMARÃES, Manoel Luís Salgado. "Nação e civilização nos trópicos: o Instituto Histórico e Geográfico Brasileiro e o projeto de uma história nacional”. Estudos Históricos, n. ${ }^{\circ}$ 1,1988 , pp. 5-27, p. 5.

${ }^{32}$ Idem, p. 6.

${ }^{33}$ PEIXOTO, Júlio Afrânio. Noções de História da Educação. São Paulo: Cia. Ed. Nacional, 1933.

${ }^{34}$ MOACYR, Primitivo. A Instrução e o Império. São Paulo: Cia Editora Nacional, 19361938 (3 volumes). 
${ }^{35}$ AZEVEDO, Fernando de. A cultura brasileira. Op. cit.

${ }^{36}$ SANTOS, Theobaldo Miranda dos. Noções de história da educação. São Paulo: Cia. Ed. Nacional, 1945.

${ }^{37}$ NUNES, Clarice. "A instrução pública e a primeira história sistematizada da educação brasileira”. Op. cit., p. 57.

${ }^{38}$ KUHLMANN JR., Moysés. Op. cit., p. 161.

${ }^{39}$ GALVÃO, Benjamin Franklin Ramiz. Apud KUHLMANN JR., Moysés. Op. cit., p. 164.

${ }^{40}$ MOACYR, Primitivo. A Instrução e o Império [...]. Op. cit.

${ }^{41}$ Dividem-se em $1^{\circ}$. volume, de 1823 a $1853,2^{\circ}$. volume, de 1854 a 1888 , e $3^{\circ}$. volume, de 1854 a 1889. MOACYR, Primitivo. A Instrução e o Império [...]. Op.cit.

${ }^{42}$ Dividem-se em $1^{\circ}$. volume, de 1834 a 1889, das Amazonas às Alagoas; $2^{\circ}$. volume, de 1835 a 1889, Sergipe, Bahia, Rio de Janeiro e São Paulo; $3^{\circ}$. volume, de 1835 a 1889, demais Províncias. MOACYR, Primitivo. A Instrução e as Províncias. São Paulo: Cia Editora Nacional, 1939-1940 (3 volumes).

${ }^{43}$ Dividem-se em: $1^{\circ}$. volume: Reforma Benjamin Constant (1890-1892); $2^{\circ}$. volume: Código Fernando Lobo (1892-1899); 3 . volume: Código Epitácio Pessoa (1900-1910); 4º volume: Reformas Rivadávia e Carlos Maximiliano (1911-1925); 5. volume: Reforma João Luiz Alves-Rocha Vaz (1923-1930); 6º volume: Ensino Profissional; $7^{\circ}$. volume: Ensino Agrônomo. MOACYR, Primitivo. A Instrução e a República. Rio de Janeiro: Imprensa Nacional, 1941-1942 (7 volumes).

${ }^{44}$ Referem-se tão somente à primeira década republicana $\left(1^{\circ}\right.$. volume, de 1890 a 1893 , e o 2. volume de 1890 a 1900), apesar de no $1^{\circ}$. volume, 68 páginas estivessem dedicadas aos períodos colonial e imperial. MOACYR, Primitivo. A Instrução pública no Estado de São Paulo. Rio de Janeiro: Imprensa Nacional, 1942 (2 volumes).

${ }^{45}$ Separata dos Anais do III Congresso de História Nacional (v.5). Separata do IHGB.

${ }^{46}$ PEIXOTO, Júlio Afrânio. [Prefácio]. MOACYR, Primitivo. A Instrução e o Império [...]; $1^{\circ}$. volume. Op. cit., p. 7.

${ }^{47}$ Tereza M.R. Fachada L. Cardoso, no verbete que escreveu sobre Moacyr ressalta, entretanto, que em raras passagens de instrução primária e secundária do município da Corte, é possível encontrar comentários do autor. FÁVERO, M. de Lourdes de A. \& BRITTO, Jader de M. (orgs.). Dicionário dos educadores no Brasil. Rio de Janeiro: Ed. UFRJ; Brasília: INEP, 2002, pp. 916-20.

${ }^{48}$ TEIXEIRA, Anísio. [Prefácio]. MOACYR, Primitivo. A Instrução e o Império [...]; 3º. volume. Op. cit., p. 5.

${ }^{49}$ MOACYR, Primitivo. O ensino público no Congresso Nacional: breve notícia. Rio de Janeiro, 1916. 
${ }^{50}$ Idem., p. 5.

${ }^{51}$ Idem., p. 206.

${ }^{52}$ As informações biográficas foram coligidas no verbete sobre o autor, elaborado por Tereza Cardoso. FÁVERO, M. de Lourdes de A. \& BRITTO, Jader de M. (orgs.). Dicionário dos educadores no Brasil. Op. cit.

${ }^{53}$ LOURENÇO FILHO, M.B. “Apresentação”. In: Instituto Nacional de Estudos Pedagógicos. Subsídios para a história da educação brasileira. Ministério da Educação e Saúde, 1942, pp. IX-XIII, p. IX.

${ }^{54}$ INSTITUTO Nacional de Estudos Pedagógicos. Subsídios para a história da educação brasileira. Ministério da Educação e Saúde, 1942-1951, 11 volumes.

${ }^{55}$ LOURENÇO FILHO, M.B. Op. cit., p. X.

${ }^{56}$ LOURENÇO FILHO, M.B. Op. cit., p. IX.

${ }^{57}$ XAVIER, Libânia Nacif. O Brasil como laboratório. Bragança Paulista: EDUSF, 1999, p. 84.

${ }^{58}$ VEIGA, Cynthia G. \& FARIA FILHO, Luciano M. "A escrita da história da educação mineira: a produção de Paulo Krüger”. In Gondra, José (org.). Dos arquivos à escrita da história: a educação brasileira entre o Império e a República. Bragança Paulista: EDUSF, 2001, pp. 37-58.

${ }^{59}$ SAVIANI, Dermeval. “Apresentação”. In: BLANCK MIGUEL (org.). Coletânea da Documentação Educacional Paranaense no período de 1854 a 1889. Brasília/ São Paulo: INEP/ SBHE, Autores Associados, 2000, p. XX.

${ }^{60}$ VIDAL, Diana G. O exercício disciplinado do olhar: livros, leituras e práticas de formação docente no Instituto de Educação do Distrito Federal (1932-1937). Bragança Paulista: EDUSF, 2001, pp. 76-77.

Em 1931, resolução semelhante iria encontrar abrigo na reforma realizada para o ensino paulista em 1931, por Lourenço Filho. MONARCHA, Carlos. Escola Normal da Praça: o lado noturno das luzes. Campinas: Ed. Unicamp, 1999, p. 333.

Em 1933, com a criação do Instituto de Educação de São Paulo, seria instalada a cadeira de Filosofia e História da Educação, rebatizada, em 1942, de História e Filosofia da Educação, nesse momento já integrada à Faculdade de Filosofia, Ciências e Letras-USP, sobre o que discorremos no item 1.3. BONTEMPI JR., Bruno. A cadeira de História e Filosofia da USP entre os anos 40 e 60: um estudo das relações entre a vida acadêmica e a grande imprensa. Doutorado, FEUSP, 2001, p. 188 e seg.

${ }^{61}$ A biografia de Peixoto foi recolhida junto ao verbete elaborado por Eliane Marta T. Lopes. FÁVERO, M. de Lourdes de A. \& BRITTO, Jader de M. (orgs.). Dicionário dos educadores no Brasil. Op. cit.

${ }^{62}$ PEIXOTO, Júlio Afrânio. Noções de História da Educação. Op. cit. 
Diana Gonçalves Vidal e Luciano Mendes de Faria Filho

${ }^{63}$ Idem., p. 220.

${ }^{64}$ PEIXOTO, Júlio Afrânio. Noções de História da Educação. Op. cit., p. 242.

${ }_{65}$ “Centenário vergonhoso”. A Manhã, Rio de Janeiro, 15 out.1927 [sem identificação de autoria].

${ }^{66}$ MENNUCCI, Sud. Cem annos de instrução pública (1822-1922), 1932, p. 38. O livro de Sud Mennucci reproduzia, em 1932, os artigos publicados n'O Estado de S. Paulo durante as comemorações do centenário da Independência. Praticamente a única referência bibliográfica utilizada na elaboração do texto foi História do Brasil, de Rocha Pombo, publicado em 1922, em edição especial, em virtude da exposição internacional no Rio de Janeiro.

${ }^{67}$ PEIXOTO, Júlio Afrânio. Noções de História da Educação. Op. cit., p. 265.

Para uma análise mais abrangente do livro de Afrânio Peixoto, ver: ROCHA, Heloisa H.P. "Recordação para professoras: a história da educação brasileira narrada por Afrânio Peixoto”. In Gondra, José (org.). Dos arquivos à escrita da história: a educação brasileira entre o Império e a República. Bragança Paulista: EDUSF, 2001, pp. 11-36.

${ }^{68}$ NUNES, Clarice. "A instrução pública e a primeira história sistematizada da educação brasileira”. Op. cit., p. 57.

$66{ }^{69}$ NUNES, Clarice. "A instrução pública e a primeira história sistematizada da educação brasileira”. Op. cit., p. 58.

${ }^{70}$ AZEVEDO, Fernando de. A cultura brasileira. Op. cit.

${ }^{71}$ PEETERS, Madre Francisca \& COOMAN, Madre Maria Augusta. Op. cit.

${ }^{72}$ ANDRADE FILHO, Bento de. História da educação. Coleção de Ensino Normal. Rio de Janeiro: Saraiva, 1941.

${ }^{73}$ Idem, p. 269.

${ }^{74}$ BELLO, Ruy de Ayres. Esboço de história da educação. São Paulo: Cia. Ed. Nacional, 1945.

${ }^{75}$ É comum associar-se o escolanovismo aos educadores liberais no Brasil, no entanto, vários educadores católicos professaram ideais da escola nova, como por exemplo, Everardo Backheuser. A este respeito ver: BACKHEUSER, Everardo. Técnica da Pedagogia Moderna. Rio de Janeiro: Ed. Globo, 1936.

${ }^{76}$ ARCHÊRO FILHO, Aquiles. "Lições de história da educação". Coleção Didática Nacional. Série Brasil — Normal. São Paulo: Edições e publicações Brasil Ed., s.d.

${ }^{77}$ Idem, p. 94.

${ }^{78}$ SANTOS, Theobaldo Miranda dos. Op. cit.

${ }^{79}$ Idem, p. 492.

${ }^{80}$ Idem, p. 498. 
${ }^{81}$ Idem, p. 503.

${ }^{82}$ AZEVEDO, Fernando de. A cultura brasileira. Op. cit.

${ }^{83}$ FERREIRA, Tito Lívio. História da Educação Lusobrasileira. São Paulo: Saraiva, 1966.

${ }^{84}$ Idem., [s.p.].

${ }^{85}$ NUNES, Clarice. "Ensino e historiografia da educação [...]”. Op. cit., p. 69.

A falta de informação biográfica sobre os outros autores impede uma análise mais cuidadosa

${ }^{86}$ LOPES, Eliane Marta \& GALVÃO, Ana Maria. História da educação. Rio de Janeiro: DP\&A, 2001, p. 28.

${ }^{87} \mathrm{Idem}, \mathrm{p} .29$.

${ }^{88}$ PEIXOTO, Júlio Afrânio. Noções de História da Educação. Op. cit.

${ }^{89}$ AZEVEDO, Fernando de. A cultura brasileira. Op. cit.

${ }^{90}$ VIDAL, Diana G. O exercício disciplinado do olhar [...]. Op. cit.

${ }^{91}$ TANURI, Leonor. "História da formação de professores”. Revista brasileira de educação, n. ${ }^{\circ} 14$, maio - ago. 2000, pp. 61-88, p. 14.

${ }^{92}$ ROMANELLI, Otaíza. História da educação no Brasil. Petrópolis: Vozes, 1978, p. 165.

${ }^{93}$ WARDE. Mirian, "Questões teóricas e de método: a história da educação nos marcos de uma história das disciplinas”. In SAVIANI, Dermeval et al. História e história da educação. O debate teórico-metodológico atual. Campinas: Autores Associados, 1998, pp. 91-92.

${ }^{94}$ Idem.

${ }^{95}$ NUNES, Clarice. "Ensino e historiografia da educação [...]". Op. cit., p. 70.

${ }^{96}$ Concebemos, aqui, acadêmica como produzida no interior das universidades. Para os anos 1930, consideramos as obras que, mesmo que escritas anteriormente ao ingresso do autor nos quadros universitários, alcançaram prestígio acadêmico. Nos limites deste artigo, nos deteremos principalmente nas fontes coligidas em São Paulo.

${ }^{97}$ AZEVEDO, Fernando de. A cultura brasileira. Op. cit.

${ }^{98}$ Idem, p. 14.

${ }^{99}$ Em 1936, Buarque de Holanda foi convidado a ser assistente do prof. Henri Hauser na cadeira de História Moderna e Contemporânea da Universidade do Distrito Federal.

${ }^{100}$ Em 1931, Freyre atuou como professor extraordinário na Universidade de Standford. No ano de 1935, assumiu a cátedra de sociologia, na Faculdade de Direito do Recife, e de antropologia na Universidade do Distrito Federal.

${ }^{101}$ HOLANDA, Sérgio Buarque de. Apud AZEVEDO, Fernando de. A cultura brasileira. Op. cit., p. 195. 
${ }^{102}$ FREYRE, Gilberto. Apud AZEVEDO, Fernando de. A cultura brasileira. Op. cit., p. 197.

${ }^{103}$ Sobre a bibliografia utilizada por Azevedo, ver TOLEDO, Maria Rita de Almeida. "As fontes d'A cultura brasileira". Horizontes, n. ${ }^{\circ}$ 14, 1996, pp. 45-142.

${ }^{104}$ PEIXOTO, Júlio Afrânio. Noções de História da Educação. Op. cit.

${ }^{105}$ CARVALHO, Marta Maria Chagas de. "A configuração da historiografia educacional brasileira”. In FREITAS, Marcos Cezar (org.). Historiografia brasileira em perspectiva. São Paulo: Contexto, Bragança Paulista: EDUSF, 1998, pp. 329-353, p. 336.

${ }^{106}$ CARVALHO, Marta Maria Chagas de. "O novo, o velho, o perigoso: relendo a cultura brasileira”. Cadernos de pesquisa, n. ${ }^{\circ} 71$, nov. 1989, pp. 29-35.

${ }^{107}$ CARVALHO, Marta Maria Chagas de. "A configuração da historiografia educacional brasileira”. Op. cit., p. 331.

${ }^{108}$ BRANDÃO, Zaia. A intelligentsia educacional: um percurso com Paschoal Lemme. Por entre as memórias e as histórias da escola nova no Brasil. Bragança Paulista: EDUSF, 1999.

${ }^{109}$ CARVALHO, Marta Maria Chagas de. “L’histoire de l'éducation au Brésil: traditions historiographiques et processus de rénovation de la discipline". Paedagogica Historica - Internacional; Journal of the History of Education, v. 36, n. * 3, 2000, pp.909-933.

${ }^{110}$ Apud. TANURI, Leonor. "Historiografia da educação brasileira; contribuição para o seu estudo na década anterior à instalação dos cursos de pós-graduação”. História da educação, n.o 3, abr. 1998, pp. 139-153, p. 141.

${ }^{111}$ A correspondência trocada por Fernando de Azevedo e Anísio Teixeira, entre 1929 e 1971, foi publicada em VIDAL, Diana G. (org.). Na batalha da educação. Correspondência entre Anísio Teixeira e Fernando de Azevedo (1929-1971). Bragança Paulista: EDUSF, 2000.

${ }^{112}$ BONTEMPI JR., Bruno. Op. cit., pp. 227 e seg.

${ }^{113}$ CARVALHO, Laerte Ramos de. As reformas pombalinas de instrução pública. São Paulo: EDUSP/ Saraiva, 1978.

Sobre os professores anteriores da cadeira, o catedrático Roldão Lopes de Barros (de 1933 a 1947) e seu assistente, José Querino Ribeiro, ver BONTEMPI JR., Bruno. Op. cit., p. 187 e seg.. Segundo Bontempi, Querino Ribeiro defendeu, em 1943, a primeira tese acadêmica sobre história da educação brasileira apresentada na FFCL-USP, Ensaios sobre a significação e importância da memória sobre a reforma dos estudos da Capitania de São Paulo, escrita em 1816 por Martins Francisco Ribeiro de Andrade Machado.

${ }^{114}$ CARVALHO, Laerte Ramos de. As reformas pombalinas de instrução pública. Op. cit., p. 8.

${ }^{115}$ CARVALHO, Laerte Ramos de. Apud BONTEMPI JR., Bruno. Op. cit., p. 215.

${ }^{116}$ CARVALHO, Laerte Ramos de. As reformas pombalinas de instrução pública. Op. cit., p. 8. 
${ }^{117}$ CARVALHO, Marta Maria Chagas de. “L'histoire de l'éducation au Brésil [...]”. Op. cit., p. 917.

${ }^{118}$ TANURI, Leonor. "Historiografia da educação brasileira [..]”. Op. cit., p. 144.

${ }^{119}$ BONTEMPI JR., Bruno. Op. cit., p. 239.

${ }^{120}$ Apud TANURI, Leonor. "Historiografia da educação brasileira [..]”. Op. cit., pp. 141-42.

${ }^{121}$ WARDE, Mirian. “Questões teóricas e de método: a história da educação nos marcos de uma história das disciplinas”. In SAVIANI, Dermeval et al. História e história da educação. O debate teórico-metodológico atual. Campinas: Autores Associados, 1998, pp. 88-99, pp. 93-94.

${ }^{122}$ MONARCHA, Carlos. "História da educação brasileira: atos inaugurais." Horizontes, n. ${ }^{\circ}$ 14, 1996, pp. 35-44, p. 36.

${ }^{123}$ CARVALHO, Laerte Ramos de. "A educação brasileira e sua periodização". In Revista Brasileira de História da Educação, n. 2, jul. - dez. 2001, pp.137-151, p. 138.

${ }^{124}$ As informações biográficas foram coligidas no verbete sobre o autor, elaborado por Bruno Bontempi Jr. FÁVERO, M. de Lourdes de A. \& BRITTO, Jader de M. (orgs.). Dicionário dos educadores no Brasil. Op. cit.

${ }^{125}$ WARDE, Mirian \& CARVALHO, Marta Maria Chagas de. "Política e cultura na produção da história da educação no Brasil”. Contemporaneidade e educação, ano V, n. ${ }^{\circ} 7,1^{\circ}$. Sem. 2000, pp.9-33, pp. 25-26.

${ }^{126}$ WARDE, Mirian \& CARVALHO, Marta Maria Chagas de. "Política e cultura na produção da história [...]”. Op. cit.

${ }^{127}$ Idem, p. 26.

${ }^{128}$ BARREIRA, Luís Carlos. Op. cit., p. 236.

${ }^{129}$ Idem, p. 244.

${ }^{130}$ WARDE, Mirian. “Contribuição da História para a Educação”. Op. cit., p. 9.

${ }^{131}$ LOPES, Eliane Marta \& GALVÃO, Ana Maria. Op. cit.

${ }^{132}$ NUNES, Clarice. "Ensino e historiografia da educação [...]”. Op. cit., p. 70.

${ }^{133}$ CATANI, D. Bárbara \& FARIA FILHO, Luciano Mendes de. "Um lugar de produção e a produção de um lugar [...]”. Op. cit., p. 115.

${ }^{134}$ SAVIANI, Dermeval. "O debate teórico e metodológico no campo da história [...]". Op. cit., p. 14.

${ }^{135}$ A este respeito indicamos, para os interessados, o número 34 do periódico Educação em Revista, da Faculdade de Educação da UFMG, que traz um dossiê com os oito principais grupos de pesquisa em atividade no País, além de uma síntese das atividades desenvolvi- 
das pela Associação Sul-Rio-Grandense de Pesquisadores em História da Educação/ASPHE.

${ }^{136}$ PERES, Eliane.; BASTOS, Maria H. C. “Associação Sul-Rio-Grandense de Pesquisadoras em História da Educação(ASPHE): a trajetória de uma rede de pesquisadores". In Educação em Revista, n. 34, dez/2001, pp. 123.

${ }^{137}$ WARDE, Mirian Jorge. “Anotações para uma Historiografia da Educação Brasileira”. Op. cit., p. 5.

${ }^{138}$ CATANI, D. Bárbara \& FARIA FILHO, Luciano Mendes de. "Um lugar de produção e a produção de um lugar [...]”. Op. cit., p. 126.

${ }^{139}$ DE CERTEAU, M. Op. cit.

${ }^{140}$ CHARTIER, Roger. "O mundo como representação". Estudos Avançados, vol. 5, n. ${ }^{\circ} 11$, jan./abr. 1991, pp. 173-191.

Artigo recebido em 12/2002. Aprovado em 4/2003.

Revista Brasileira de História, vol. 23, nº 45 